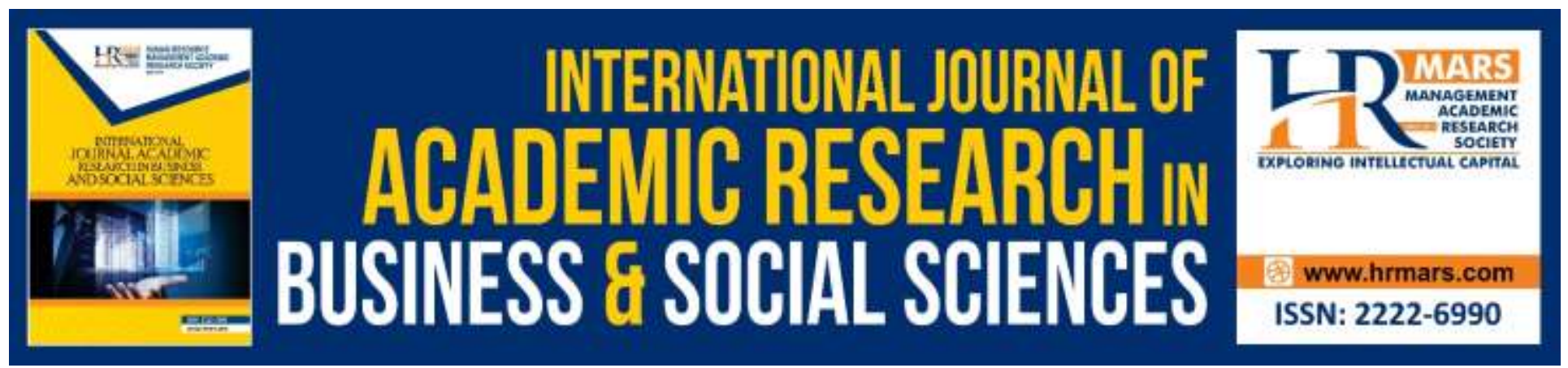

\title{
Influence of Entrepreneurial Tendencies on Uptake of Access to Government Procurement Opportunities by the Youth A Study of ISIOLO County, Kenya
}

Ann Teresa Wanjiru Kangethe, Fredrick Ephraim Khaunya Mukabi, David Newton Simiyu

To Link this Article: http://dx.doi.org/10.6007/IJARBSS/v10-i4/7115

DOI:10.6007/IJARBSS/v10-i4/7115

Received: 23 February 2020, Revised: 19 March 2020, Accepted: 30 March 2020

Published Online: 14 April 2020

In-Text Citation: (Kangethe et al., 2020)

To Cite this Article: Kangethe, A. T. W., Mukabi, F. E. K., \& Simiyu, D. N. (2020). Influence of Entrepreneurial Tendencies on Uptake of Access to Government Procurement Opportunities by the Youth A Study of ISIOLO County, Kenya. International Journal of Academic Research in Business and Social Sciences, 10(4), 132-148.

Copyright: (C) 2020 The Author(s)

Published by Human Resource Management Academic Research Society (www.hrmars.com)

This article is published under the Creative Commons Attribution (CC BY 4.0) license. Anyone may reproduce, distribute, translate and create derivative works of this article (for both commercial and non-commercial purposes), subject to full attribution to the original publication and authors. The full terms of this license may be seen at: http://creativecommons.org/licences/by/4.0/legalcode

Vol. 10, No. 4, 2020, Pg. 132 - 148

Full Terms \& Conditions of access and use can be found at http://hrmars.com/index.php/pages/detail/publication-ethics 


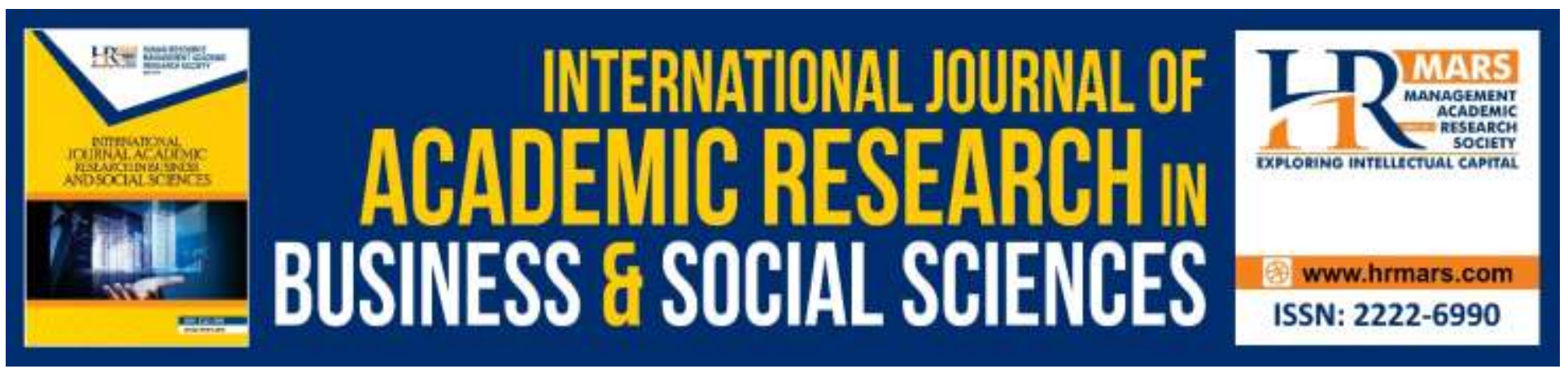

\title{
Influence of Entrepreneurial Tendencies on Uptake of Access to Government Procurement Opportunities by the Youth A Study of ISIOLO County, Kenya
}

\author{
Dr. Ann Teresa Wanjiru Kangethe, Dr. Fredrick Ephraim Khaunya \\ Mukabi, Mr. David Newton Simiyu \\ Kenya School of Government, Embu Campus \\ Email: ann.kangethe@ksg.ac.ke,fredrick.mukabi@ksg.ac.ke,david.simiyu@ksg.ac.ke
}

\begin{abstract}
Access to Government Procurement Opportunities (AGPO) is an initiative by the Kenyan Government to empower the Youth, Women and Persons With Disabilities (PWDs) through preferential treatment while seeking Government Procurement Opportunities. The aim of the AGPO initiative is to facilitate the enterprises owned by Youth, Women and PWDs to participate and benefit from at least thirty percent $(30 \%)$ of the Government tenders. However, considering the numerous challenges experienced, the determinants of this initiative and how they influence the uptake of this opportunity is not clear and hence this study while narrowing on the independent parameters of Entrepreneurial Tendencies sought to correlate with the dependent variable which was the Uptake of AGPO. Using the descriptive research design with inferential statistics as tools of analysis, and with a sample of 55 respondents drawn from the Three (3) Sub-Counties, namely; Isiolo, Garbatulla, and Merti, all in Isiolo County in Kenya. The researchers correlated the independent variable with the dependent variable. The study found that Entrepreneurial Tendencies had a moderate positive correlation with the Uptake of AGPO, as it was established that the youth were able to seek and exploit opportunities and had high propensity to undertake risks. The study recommends that the County Government of Isiolo and other agencies such as development partners should come up with new initiatives on ways of inculcating an entrepreneurial culture and assist the youth to be innovative through development of new products and provision of services.
\end{abstract}

Keywords: Determinants; Access to Government Procurement Opportunities; AGPO; Innovation; Proactiveness, Risk Taking Propensity; Entrepreneurial Tendencies, Uptake

\section{Statement of the Research Problem}

The AGPO initiative by the Government of Kenya (GOK) through the National Treasury was to facilitate the enterprises owned by Women, PWDs and Youth to be able to access, participate and benefit from the various Government Procurement Opportunities. 
INTERNATIONAL JOURNAL OF ACADEMIC RESEARCH IN BUSINESS AND SOCIAL SCIENCES Vol. 10, No. 4, April, 2020, E-ISSN: 2222-6990 @ 2020 HRMARS

This was to be made possible through the implementation of the legal requirement encapsulated in the Constitution of Kenya (COK) 2010 article 227 and executed through the Public Procurement and Disposal Act (PPADA), 2015 through which 30\% of Government Procurement Opportunities were to be set aside specifically for enterprises owned by these groups.

However, the said beneficiaries have tended not to take advantage of this opportunity as evidenced by Annual Reports from the National Treasury and research by Non-Governmental Organizations (NGOs).

According to the National Treasury Report on AGPO, 2018 less than 40\% of the youth, particularly in rural areas have picked up the challenge to utilize this opportunity and procuring entities are finding it difficult to engage these beneficiaries for varied reasons. Similarly, research by Hivos East Africa in 2018 on 'Kenya's Efforts to Empower Women, Youth and PWDs through Public Procurement' indicated that only $36 \%$ of applicants reported to have won tenders, $66 \%$ lack capital, $60 \%$ had challenges in getting paid after delivery and all indicated that procurement procedures and criteria are complex, burdensome, costly for new entities, too technical requiring specialized bidding skills and have limiting compliance costs.

The purpose of this study therefore, was to establish the possible reasons which could account for these challenges, considering that these Government procuring entities are countrywide and yet the Youth, Women and PWDs still constitute the low-income cadre as per the Kenya National Housing and Population Census of 2009.

\section{Research Objective}

The objective of the study was to determine the influence of Entrepreneurial Tendencies on Uptake of AGPO by the Youth in Isiolo County.

\section{Research Hypothesis}

The hypothesis discussed, assumed that there is a relationship between the research variable; Entrepreneurial Tendencies and Uptake of AGPO after review of literature.

$\mathbf{H}_{\mathbf{0 1}}$ : Entrepreneurial Tendencies does not have a statistically significant relationship with the Uptake of AGPO by the Youth in Isiolo County. 
INTERNATIONAL JOURNAL OF ACADEMIC RESEARCH IN BUSINESS AND SOCIAL SCIENCES

Vol. 10, No. 4, April, 2020, E-ISSN: 2222-6990 @ 2020 HRMARS

\section{Conceptual Framework}

The study conceptualized that Entrepreneurial Tendencies influence the Uptake of AGPO. The relationship is shown in Figure 1.

Independent Variable

Dependent Variable

Entrepreneurial Tendencies

- Level of Innovation

- Pro-activeness

- $\quad$ Propensity to Take Risk

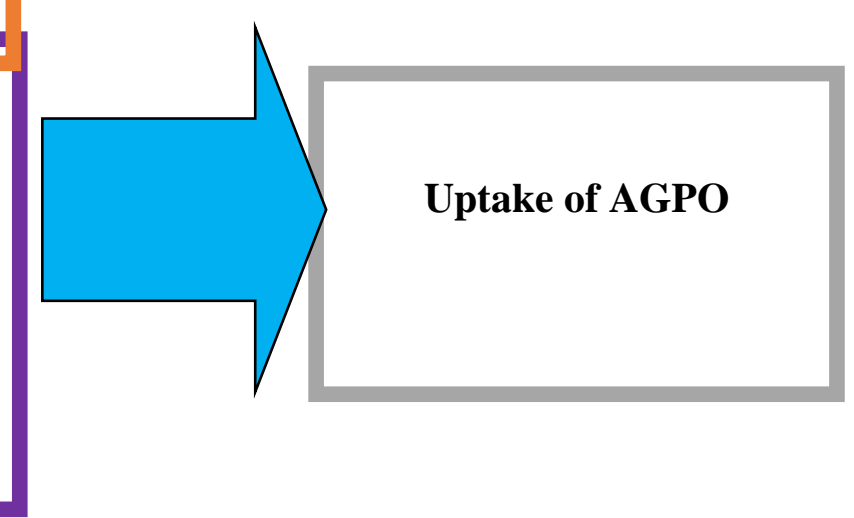

Figure 1: Conceptual Model

(Source: Authors. 2019)

\section{Literature Review}

\section{Theoretical Framework}

The theory employed in this study was Hagen's Theory of Entrepreneurship. This theory of entrepreneurial behavior was propounded by Hagen Everett (Deakins \& Freel, 2009).It is also referred to as the Withdrawal of Status Respect Theory. Hagen attributed the withdrawal of status respect of a group to the genesis of entrepreneurship. That the withdrawal acts as a trigger mechanism for changes in personality formation. Status withdrawal occurs when members of a certain group or party perceive that their purpose, goals, values and aspirations are not respected and considered to be important by another group that the subjects hold with high esteem and they also respect.

One group perceives that the other group is not reciprocating the initiatives that the other group is providing. Hagen advanced that this perception could trigger various reactions and create different personality traits such as; Retreatist where the entrepreneur will continue to perform the day to day duties but remain indifferent to his work or status; Ritualist, meaning that the entrepreneurs works as per the norms in the society but has no hope of improving the business performance or the current status; Reformist are rebellious and will always try to bring in new ways of working and a new community and lastly are the Innovators who are creative and try to achieve their set goals.

For the Youth to regain the lost prestige and glory, it is imperative for them to become more active and aggressive thereby giving rise to many entrepreneurs in the society. Hagen's theory was supported by David McClelland who admitted that a suppressed community or group will always exhibit creative Entrepreneurial Tendencies in business undertakings. 
INTERNATIONAL JOURNAL OF ACADEMIC RESEARCH IN BUSINESS AND SOCIAL SCIENCES Vol. 10, No. 4, April, 2020, E-ISSN: 2222-6990 @ 2020 HRMARS

McClelland stated that the behavior of such groups could arouse achievement in its members but its extent depended upon the initial level of incentive and the means available to the groups to realize its achievement motivation. Hagen sees the entrepreneur as a creative problem solver interested in things in the practical and technological realm and driven by a duty to achieve. The theory was found relevant in this study as it helped to explain the variables; Entrepreneurial Tendencies and Uptake of AGPO by the Youth.

\section{Empirical Review of Literature}

A huge body of literature exists which examine various determinants of the utilization of AGPO by the target group. In Kenya, AGPO is an affirmative action intended to empower Youth, Women and PWDs, by setting aside thirty percent (30\%) of all public procurement in Kenya for the targeted group (PPADA, 2015).The AGPO initiative is founded in the COK, 2010, article 227 on the fair, equitable, transparent and cost-effective public procurement of goods and services, article 55 on affirmative action and the PPADA, 2015.

A study conducted by (Nkonge et al. 2013) in Thika on challenges facing Small and Medium Enterprise (SMEs) Suppliers when bidding for Government tenders, established that the existence of the legal framework makes it difficult for upcoming SMEs to compete with the established firms in the market. This acted as a discouragement for SMEs to participate in the public procurement.

A similar study conducted by International Trade Centre (ITC) in 2014 on challenges that face women and youth in Developed and Developing economies in Government procurement, found out that lack of information about tender opportunities, overly complex and burdensome tender procedures, and failure by those agencies to promptly pay women-based businesses influenced uptake of AGPO by the targeted groups.

According to UN Women Report of 2006, women entrepreneurs face many challenges when participating in public procurement which include; Government rules and regulations, lack of access to finance, assets, information technology, infrastructure and other facilities that enable their efficiency and business growth.

Nduta et al. (2015) undertook a study with the main objective to determine factors affecting youth participation in public procurement in Mombasa County. The study documented that, lack of awareness on compliance, lack of effective regulations and financial availability influenced participation of the youth in the public procurement.

Mwangi (2017) carried out a study to determine Compliance of AGPO regulations for Women, Youth and PWDs by Public Universities in Kenya. The research findings revealed that prequalification criteria negatively contributed to the level of compliance with AGPO. The study further revealed that elaborate selection procedures lead to a higher level of compliance with AGPO for special groups in Kenya.

A study carried out by Wleh (2013) to establish factors that influenced the youth uptake of Government Procurement Opportunities in Ministries concluded that access to information, finance, legal framework and ethics in procurement influenced Uptake of AGPO by the youth.

Ngugi and Mugo (2007) in a similar study on an examination of procurement activities on the operation and effectiveness of Ministries in Kenya, established that there was need for procurement activities to be carried out by qualified staff with high professional and ethical standards, using sound procedures anchored on appropriate policies and regulations. 
INTERNATIONAL JOURNAL OF ACADEMIC RESEARCH IN BUSINESS AND SOCIAL SCIENCES Vol. 10, No. 4, April, 2020, E-ISSN: 2222-6990 @ 2020 HRMARS

\section{Entrepreneurial Tendencies and Uptake of AGPO}

Entrepreneurial Tendencies refers to multidimensional concepts that are useful at the organizational or entrepreneur's level, which exemplifies entrepreneur's or firms entrepreneurial actions and includes one or several of these magnitudes: Innovativeness, Pro-activeness and Risk-Taking Propensity. (Irungu, 2008: Lumpkin and Dess, 1996; Nyambariga, 2012).When Young people exhibit such Entrepreneurial Alignment, they get inclined to participate in business activities including AGPO. One approach to enhancing entrepreneurial activity and enterprise growth in Kenya is to create an entrepreneurial culture among the youth (Nelson \& Mburugu, 1991; Gibb, 2000). The Entrepreneurial Propensities discussed in this study that explained the reasons behind the uptake of AGPO among the Young included:

\section{Level of Innovation}

Joseph Schumpeter is credited for being amongst the first scholars to emphasize the role of innovation in the entrepreneurial process which entails interrogating the status quo within the business environment. He stressed on the critical role of an entrepreneur as an innovator who implements change in an economy by introducing new goods or new methods of production. In the Schumpeterian view, any entrepreneur including young people are disruptive forces in any economy playing the role of engaging in the beneficial process of creative destruction in which the introduction of new products results in the obsolescence or failure of others (Mwaura et al., 2015). When the youth engross in innovative activities they are able to create wealth through the introduction of new goods or services, re-allocating resources from existing firms to new firms and growth.

According to (Lumpkin \& Dess, 1996), "innovativeness reflects a tendency for an enterprise "to engage in and support new ideas, novelty, experimentation, and creative processes that may result in new products, services, or technological processes". Innovation is an important means of pursuing opportunities including AGPO and so is an important component of Entrepreneurial Orientation that the youth should harness to remain vibrant in the field of business (Lumpkin \& Dess, 1996).

\section{Pro-activeness}

Pro-activeness is another entrepreneurial characteristic critical for the youth to engage in business with the Government. Pro-activeness is related to initiative and first-mover advantages and to "taking initiative by anticipating and pursuing new opportunities" (Lumpkin \& Dess, 1996).

The Oxford Dictionary defines Pro-activeness as "acting in anticipation of future problems, needs, or changes". Lumpkin and Dess (1996) argued that Pro-activeness may be essential because it suggests a forward-looking perspective that is accompanied by innovation and entrepreneurial activity. Proactiveness relates to taking advantage of market prospects in entrepreneurship by "seizing the available initiative and acting opportunistically in order to shape the environment, that is, to influence trends and, perhaps, even to create the demand". The characteristics of a Pro-active youth involve assertiveness and progressive tactics towards rival enterprises in the same market segment, such enterprises shape their environments by actively seeking and exploiting opportunities.

Proactive firms introduce new products, technologies, administrative techniques to shape their environment and not react to it (Callaghan, 2009). 
INTERNATIONAL JOURNAL OF ACADEMIC RESEARCH IN BUSINESS AND SOCIAL SCIENCES Vol. 10, No. 4, April, 2020, E-ISSN: 2222-6990 @ 2020 HRMARS

\section{Risk-Taking Propensity}

Richard Cantillon, a French Classical economist and businessman, in his essay on the "Nature of Commerce", defined entrepreneurship as a risk bearing function, which entails having a foresight and willingness to assume risk and take the action required to make a profit. The Youth in Kenya to effectively utilize AGPO approaches, calls for the need to accelerate the importance of understanding the concept of risk taking characteristic. This entails having the willingness to become bearers of uncertainties while engaging in AGPO initiatives. Risk-taking relates to a business readiness to pursue opportunities despite uncertainty around the eventual success (Deakins \& Freel, 2012). It necessitates acting boldly without knowing the consequences of risk-taking, it is the firm knowingly devoting the resources to projects with chances of high returns but may also entail a possibility of higher failure (Mahmoud \& Hanafi, 2013).

There are three (3) categories of individuals in terms of analyzing their propensity to take a risk, i.e. risk-takers, risk-neutral and risk-averse. Effective and efficient entrepreneurs undertake moderate, calculated and rational risks. The high propensity to undertake risks have also been associated with higher performance by individuals. (Deakins \& Freel, 2012; Callaghan, (2009). Lumpkin and Dess (1996), "identified three (3) types of risks that businesses face in pursuing entrepreneurial activities"; Business's Risks associated with entering new markets or supporting unproven technologies; Financial Risks relating to the financial exposure required and the risk/return profile of the new venture. It may include borrowing heavily or obligating large proportions of their resources and Personal Risks referring to the repute effects of success or failure in the business. Drucker argued that entrepreneurs are not typically risk seekers rather, like any other rational individuals, they take steps to minimize risks, and this may involve developing strategies that entail a higher acceptance for risk, but also the calculation of risks.

\section{The Research Gap}

In summary, most of the studies reviewed showed that; access to information, access to finance, Legal and Regulatory Framework, ethics in procurement, are key determinants of AGPO by the youth. The existing body of knowledge was not sufficient to show the influence of the independent variable; Entrepreneurial tendencies and the dependent variable Uptake of AGPO initiatives by Youth in Kenya. The literature reviewed generally outlined the external environmental factors influencing participation of youth in government business opportunities. The literature laid little emphasis on the internal intrinsic dynamics such as inculcation of entrepreneurial spirit and how it imparted on the behavior of the Youth in operating entrepreneurial ventures. This study sought to fill the research gap by exploring the influence of Entrepreneurial Tendencies on Uptake of AGPO among the Youth in Isiolo County.

\section{Research Methodology}

The purpose of this study was to determine the influence of Entrepreneurial Tendencies on Uptake of AGPO. To realize this, the study undertook a descriptive survey design. The study population targeted the Three (3) Sub-Counties, namely ; Isiolo, Garbatulla, and Merti in Isiolo County in Kenya. The target group constituted 55 Youth from Isiolo County that were attending a Course at the Kenya School of Government, Embu Campus. 
INTERNATIONAL JOURNAL OF ACADEMIC RESEARCH IN BUSINESS AND SOCIAL SCIENCES Vol. 10, No. 4, April, 2020, E-ISSN: 2222-6990 @ 2020 HRMARS

The study used questionnaires to collect data. The questionnaire had closed-ended and open-ended questions. The closed-ended questions made use of a five-point Likert scale where respondents were required to fill according to their level of agreement with the statements. Many researchers prefer to use a Likert-type scale because it's very easy to analyze statistically (Jackson, 2009).

Descriptive statistics such as frequencies and percentages were used to analyze the data. Pearson correlation coefficient was used to measure the strength and direction of the relationship between the dependent variable and independent variable. Correlation technique allowed the researchers to analyze the degree and direction of the relationship between the dependent variable and the independent variable.

\section{Operationalization of the Study Variables}

The responses in the questionnaire were rated on a scale of 1-5, where 1 represented strongly disagree and 5, strongly agree.

Table 1. Operationalization of the Study Variables

\begin{tabular}{|c|c|}
\hline Variable & Indicators \\
\hline Dependent Variable & Business Ownership Status \\
\hline \multirow[t]{2}{*}{ (Uptake of AGPO) } & Business Growth \\
\hline & Business Profitability \\
\hline Independent Variable & (Innovation, Pro-activeness, Risk Taking) \\
\hline \multirow[t]{8}{*}{ (Entrepreneurial Tendencies) } & I always engage in high-risk activities \\
\hline & I aggressively seek and exploit opportunities \\
\hline & I have new products/services all the time \\
\hline & I always have opportunities to learn new ideas \\
\hline & $\begin{array}{l}\text { As an entrepreneur am rarely in control of my life and } \\
\text { business }\end{array}$ \\
\hline & $\begin{array}{l}\text { I am always very certain on the decisions I make } \\
\text { concerning the future }\end{array}$ \\
\hline & I rarely anticipate future wants and needs in the market \\
\hline & I always respond to what competitors bring in the Market \\
\hline
\end{tabular}

(Source: Authors, 2019)

\section{Interpretation of the Correlation Coefficients of the Study Variable}

$\mathrm{H}_{\mathrm{oi}}: \boldsymbol{\rho}_{i}=\mathbf{0}$ versus $\mathrm{H}_{\mathrm{oi}}: \boldsymbol{\rho}_{i} \neq \mathbf{0}$

If the hypothesis is rejected then the Independent Variable $X_{i}$ had a statistically significant relationship or association with the dependent variable Y (Chen \& Popovich, 2002).

The decision to reject or fail to reject the Null Hypothesis was based on the statistical significance of the correlation coefficients $(p \leq 0.05)$.

\section{Research Findings and Discussions}

This section reports the findings of the study. It begins with the respondents' response rate, the respondents' demography, descriptive analysis of the study variables using proportions and 
INTERNATIONAL JOURNAL OF ACADEMIC RESEARCH IN BUSINESS AND SOCIAL SCIENCES Vol. 10, No. 4, April, 2020, E-ISSN: 2222-6990 @ 2020 HRMARS

culminates with the inferential statistics of the study variables using the Pearson's correlation coefficient $r$.

Table 2. Response Rate

\begin{tabular}{lccc}
\hline Item & $\begin{array}{c}\text { Administered } \\
\text { Questionnaires }\end{array}$ & $\begin{array}{c}\text { Returned } \\
\text { Questionnaires }\end{array}$ & $\begin{array}{c}\text { Percentage } \\
\text { Remaining }\end{array}$ \\
\hline Respondents & 55 & 55 & $100 \%$ \\
\hline
\end{tabular}

(Source: Authors, 2019)

Respondents Demography

Respondents Gender

From Table 3 and Figure 2 sixty-seven percent (67\%) of the respondents were male and thirty-three percent (33\%) were female.

Table 3. Gender of Respondents

( $N=55)$

\begin{tabular}{rrc}
\hline Gender & $N$ & $\%$ \\
\hline Male & 37 & 67.0 \\
Female & 18 & 33.0 \\
$\mathrm{~N}$ & 55 & 100.0 \\
\hline
\end{tabular}

(Source: Survey Data, 2019)

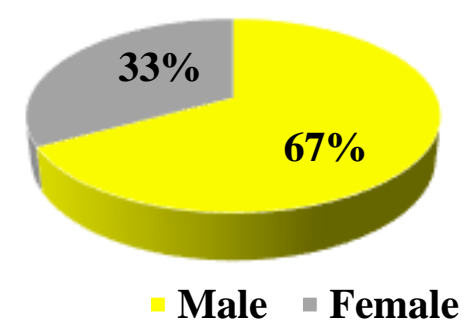

Figure 2 Gender of Respondents

(Source: Survey Data, 2019) 
INTERNATIONAL JOURNAL OF ACADEMIC RESEARCH IN BUSINESS AND SOCIAL SCIENCES Vol. 10, No. 4, April, 2020, E-ISSN: 2222-6990 @ 2020 HRMARS

\section{Age of Respondents}

From Figure 3 seventy-three percent (73\%) of the respondents were between 20-29 years and twenty-seven percent (27\%) were between $30-39$ years.

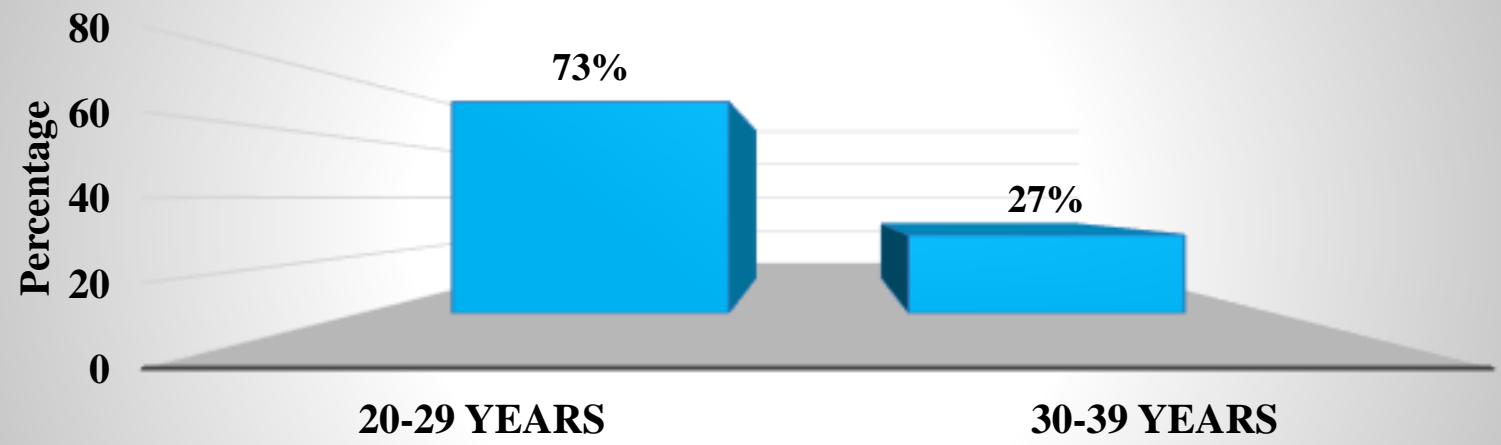

Figure 3: Age of Respondents

(Source: Survey Data, 2019)

\section{Highest Academic Qualification}

From Figure 4, sixteen percent (16\%) had KCPE, twenty-nine percent (29\%) had KCSE, twenty-one percent (21\%) had Certificate, twenty-one percent (21\%) had Diploma and eleven percent (11\%) had a Degree.

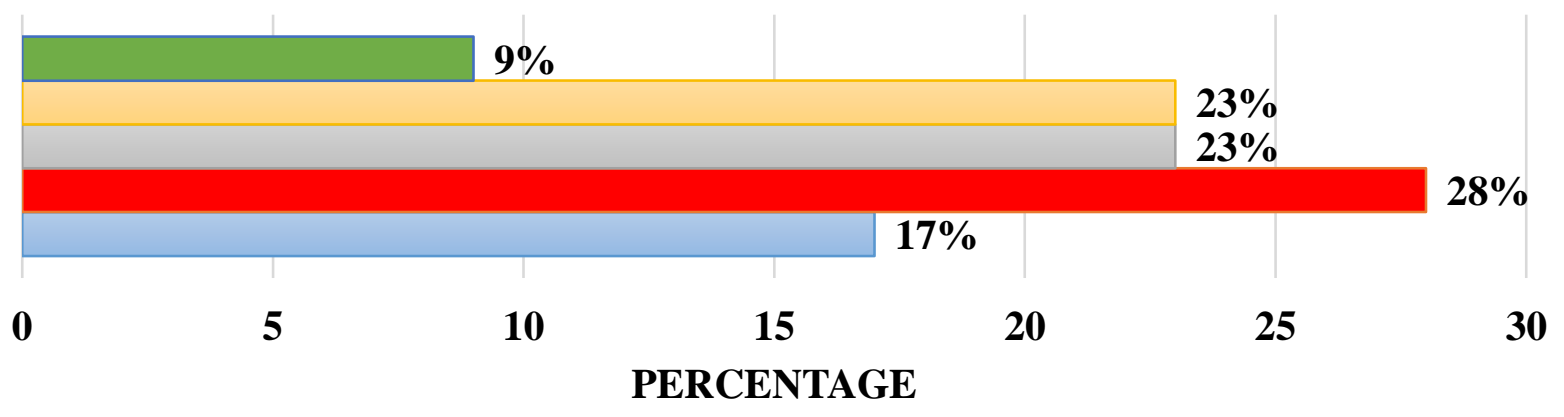

\section{$\square$ DEGREE $\square$ DIPLOMA $\square$ CERTIFICATE $\square$ KCSE $\square$ KCPE}

Figure 4: Respondents Highest Level of Education

(Source: Survey Data, 2019)

\section{Respondents' Sub-County}

From Table 4, majority of the respondents, that is eighty percent (80\%) were from Isiolo, eleven percent (11\%) from Garbatulla and nine percent (9\%) from Merti Sub County.

Table 4. Respondents Sub-County

\begin{tabular}{rcc}
\hline Sub -County & $\boldsymbol{n}$ & $\boldsymbol{\%}$ \\
${$\cline { 3 - 3 }$} }$ & 44 & 80.0 \\
Garbatulla & 6 & 11.0 \\
Merti & 5 & 9.0 \\
$\mathrm{~N}$ & 55 & 100.0 \\
\hline
\end{tabular}

(Source: Survey Data, 2019) 
INTERNATIONAL JOURNAL OF ACADEMIC RESEARCH IN BUSINESS AND SOCIAL SCIENCES Vol. 10, No. 4, April, 2020, E-ISSN: 2222-6990 @ 2020 HRMARS

\section{The proportion of Respondents with Businesses}

From Table 5 and Figure 5 forty-four percent (44\%) of the respondents owned some form of business while fifty-six percent (56\%) did not own a business.

Table 5. Business Ownership

(N = 55)

\begin{tabular}{rcc}
\hline Response & $\boldsymbol{n}$ & $\boldsymbol{\%}$ \\
\hline Yes & 24 & 44.0 \\
No & 31 & 56.0 \\
$\mathrm{~N}$ & 55 & 100.0 \\
\hline
\end{tabular}

(Source: Survey Data, 2019)

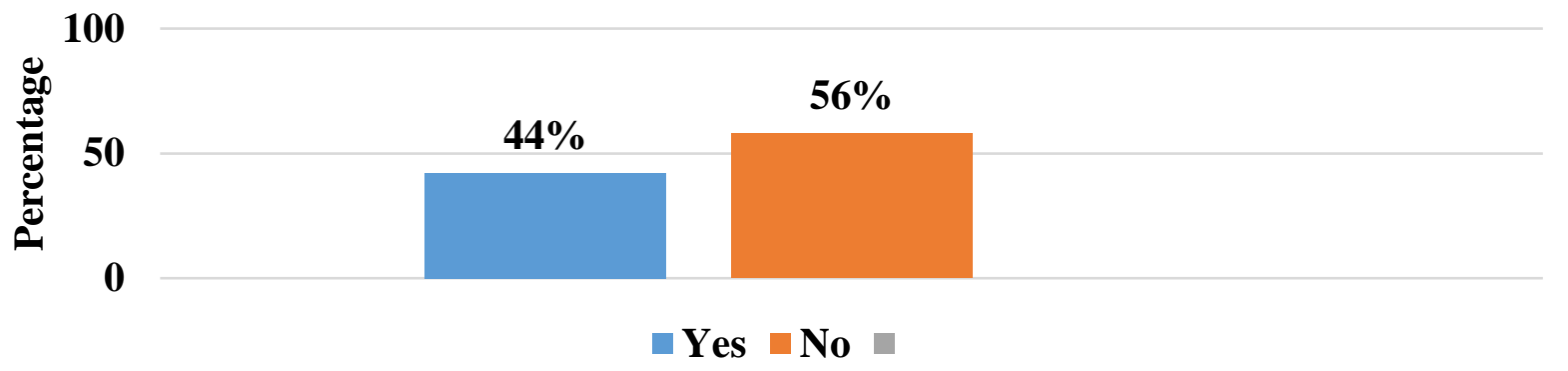

Figure 5: Respondents Business Ownership

(Source: Survey Data, 2019)

Type of Business Ownership

From Table 6 and Figure 6, sixty-two percent (62\%) had sole proprietorship type of business, twentyseven percent $(27 \%)$ had partnerships and eleven percent $(11 \%)$ had limited companies.

Table 6. Business Ownership

$(\mathrm{N}=55)$

\begin{tabular}{rcc}
\hline Type of Business & $\boldsymbol{n}$ & $\%$ \\
\hline Sole proprietorship & 16 & 62.0 \\
Partnership & 7 & 27.0 \\
Limited Company & 3 & 11.0 \\
$\mathrm{~N}$ & 26 & 100.0 \\
\hline
\end{tabular}

(Source: Survey Data, 2019)

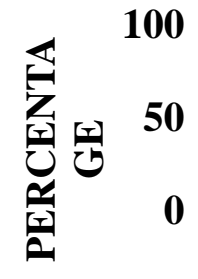

Sole Proprietorship

Partnership

Limited Company

Figure 6: Business Ownership

(Source: Survey Data, 2019) 
INTERNATIONAL JOURNAL OF ACADEMIC RESEARCH IN BUSINESS AND SOCIAL SCIENCES Vol. 10, No. 4, April, 2020, E-ISSN: 2222-6990 @ 2020 HRMARS

\section{Do you own a business * what is the type of Business Ownership Cross tabulation}

From Table 7 sixty-seven percent (67\%) owned a business and were sole proprietors.

Twenty-one percent (21\%) owned partnerships, whilst twelve percent (12\%) did own a business but were in Limited Companies. Twenty-nine percent (29\%) did not own a business but were in partnerships.

Table 7. Cross Tabulation-Business Ownership and Type of Business

\begin{tabular}{|c|c|c|c|c|c|c|}
\hline & & & \multicolumn{3}{|c|}{ What is the type of Business Ownership } & \multirow[t]{2}{*}{$\%$} \\
\hline & & & $\begin{array}{c}\text { Sole } \\
\text { proprietorship }\end{array}$ & $\begin{array}{l}\text { Partner- } \\
\text { ship }\end{array}$ & $\begin{array}{l}\text { Limited } \\
\text { company }\end{array}$ & \\
\hline \multirow{6}{*}{$\begin{array}{l}\text { Do you } \\
\text { own a } \\
\text { business }\end{array}$} & \multirow{3}{*}{ Yes } & $N$ & 16 & 5 & 3 & 24 \\
\hline & & Do you own a business & $67.0 \%$ & $21.0 \%$ & $12.0 \%$ & $100.0 \%$ \\
\hline & & $\begin{array}{l}\text { What is the type of } \\
\text { Business Ownership }\end{array}$ & $100.0 \%$ & $71.0 \%$ & $100.0 \%$ & $92.3 \%$ \\
\hline & \multirow{3}{*}{ No } & $N$ & 0 & 2 & 0 & 2 \\
\hline & & Do you own a business & $0.0 \%$ & $100.0 \%$ & $0.0 \%$ & $100.0 \%$ \\
\hline & & $\begin{array}{l}\text { What is the type of } \\
\text { Business Ownership }\end{array}$ & $0.0 \%$ & $29.0 \%$ & $0.0 \%$ & $8.0 \%$ \\
\hline \multirow{3}{*}{$\%$} & & $N$ & 16 & 7 & 3 & 26 \\
\hline & & Do you own a business & $62.0 \%$ & $27.0 \%$ & $11.0 \%$ & $100.0 \%$ \\
\hline & & $\begin{array}{l}\text { What is the type of } \\
\text { Business Ownership }\end{array}$ & $100.0 \%$ & $100.0 \%$ & $100.0 \%$ & $100.0 \%$ \\
\hline
\end{tabular}

(Source: Survey Data, 2019)

\section{Descriptive Statistics of the Study Variables}

\section{Entrepreneurial Tendencies and Uptake of AGPO by the Youth in Isiolo County}

From Table 8, fifty-five percent (55\%) agreed that they engaged in high-risk activities hence a high propensity to undertake risks. These findings are in tandem with the works of Kuratko \& Hodgettes, 2007 that Risk-taking is frequently associated with entrepreneurial performance and the general successful entrepreneurs are risk-takers.Eighty-five percent (85\%) agreed that they aggressively pursued and exploited business opportunities implying that they possessed Pro-activeness which is an entrepreneurial orientation dimension.

The findings of this study agree with scholarly works of (Callaghan, 2009) that Proactive firms introduce new products, technologies, administrative techniques to shape their environment and not react to it.

Fifty-two percent (52\%) disagreed on having new products and services all the time. Seventy-nine percent (79\%) agreed that they do have opportunities to learn new ideas meaning they had strong desire to be creative and innovative. Fifty percent (50\%) agreed that as entrepreneurs, they are rarely in control of their life. Ninety-three percent (93\%) agreed that they were very certain on the decisions they make concerning the future. Seventy-four percent (74\%) agreed that they rarely anticipate future wants and needs in the market. Eighty-four percent (84\%) agreed that they always respond to what the competitors bring in the market. 
INTERNATIONAL JOURNAL OF ACADEMIC RESEARCH IN BUSINESS AND SOCIAL SCIENCES Vol. 10, No. 4, April, 2020, E-ISSN: 2222-6990 @ 2020 HRMARS

Table 8. Descriptive Statistics of the Study Variable, Entrepreneurial Tendencies $(\mathrm{N}=55)$

\begin{tabular}{|c|c|c|c|c|c|c|}
\hline \multirow[t]{2}{*}{ Parameter } & $\begin{array}{l}\text { Strongly } \\
\text { Disagree }\end{array}$ & Disagree & $\begin{array}{l}\text { Don't } \\
\text { Know }\end{array}$ & Agree & $\begin{array}{l}\text { Strongly } \\
\text { Agree }\end{array}$ & $\%$ \\
\hline & \multicolumn{6}{|c|}{$\%$} \\
\hline $\begin{array}{l}\text { I always engage in high risk } \\
\text { activities }\end{array}$ & 16.0 & 26.0 & 4.0 & 43.0 & 12.0 & 100.0 \\
\hline $\begin{array}{l}\text { aggressively seek and } \\
\text { exploit opportunities }\end{array}$ & 2.0 & 9.0 & 4.0 & 66.0 & 19.0 & 100.0 \\
\hline I have new & & & & & & \\
\hline $\begin{array}{l}\text { products/services all the } \\
\text { time }\end{array}$ & 2.0 & 50.0 & 10.0 & 28.0 & 10.0 & 100.0 \\
\hline $\begin{array}{l}\text { I have an opportunity to } \\
\text { learn new ideas }\end{array}$ & - & 19.0 & 2.0 & 56.0 & 23.0 & 100.0 \\
\hline $\begin{array}{l}\text { As an entrepreneur am } \\
\text { rarely in control of my life } \\
\text { I am always very certain on }\end{array}$ & 17.0 & 29.0 & 4.0 & 35.0 & 15.0 & 100.0 \\
\hline $\begin{array}{l}\text { the decisions I make } \\
\text { concerning the future }\end{array}$ & 2.0 & 6.0 & - & 62.0 & 31.0 & 100.0 \\
\hline I rarely anticipate future & & & & & & \\
\hline $\begin{array}{l}\text { wants and needs in the } \\
\text { market }\end{array}$ & 10.0 & 10.0 & 8.0 & 62.0 & 12.0 & 100.0 \\
\hline $\begin{array}{l}\text { I always respond to what } \\
\text { the competitors bring in the } \\
\text { market }\end{array}$ & 4.0 & 4.0 & 8.0 & 67.0 & 17.0 & 100.0 \\
\hline
\end{tabular}

(Source: Survey Data, 2019)

Inferential Statistics of the Study Variable: Entrepreneurial Tendencies and Uptake of AGPO Table 9 indicated that,the independent variable, Entrepreneurial Tendencies had a statistically significant moderate positive correlation with the dependent variable Uptake of AGPO $r(51)=.634 p$ $<.05$ hence we REJECT the Null Hypothesis $\mathrm{H}_{\mathbf{0} 1}$ : Entrepreneurial Tendencies do not have a statistically significant relationship with the Uptake of AGPO by the Youth in Isiolo County.

Table 9. Correlation Coefficients between the Independent Variable and the Dependent Variable $(\mathbf{N}=55)$

\begin{tabular}{llc}
\hline Determinant of AGPO $\left(\mathbf{X}_{\mathbf{i}}\right)$ & Uptake of AGPO $(\mathbf{Y})$ \\
\hline & Pearson Correlation & $.634^{*}$ \\
Entrepreneurial Tendencies & Sig. (2-tailed) & .039 \\
& $\mathrm{~N}$ & 55 \\
\hline
\end{tabular}

*. Correlation is significant at the 0.05 level (2-tailed).

(Source: Survey Data, 2019) 
INTERNATIONAL JOURNAL OF ACADEMIC RESEARCH IN BUSINESS AND SOCIAL SCIENCES

Vol. 10, No. 4, April, 2020, E-ISSN: 2222-6990 @ 2020 HRMARS

\section{Conclusion and Recommendations \\ Conclusion}

The study established that, fifty-two percent (52\%) disagreed on having new products and services all the time hence the need to embrace innovation and creativity in businesses. Mwaura et al., (2015) espoused that among the critical characteristic of an entrepreneur involves exhibition of innovative predispositions and implementation of change in an economy by introducing new goods or new methods of production.

The study established that seventy four percent (74\%) of the respondents rarely anticipate future wants and needs in the market hence the need for the youth to be Pro-active. Lumpkin and Dess, (1996) considered Pro-activeness as a prerequisite which was associated with initiative and firstmover advantages and to "taking initiative by anticipating and pursuing new opportunities".

The study concluded that Entrepreneurial Tendencies had a moderate positive correlation with the Uptake of AGPO, as it was observed that fifty five percent (55\%) of the respondents had a High Propensity to undertake Risks. The findings are in congruence with the works of Mahmoud and Hanafi, (2013) that risk-taking necessitates acting boldly without knowing the consequences of any business actions. It encompasses a firm knowingly devoting the resources to projects with chances of high returns but may also compel a possibility of higher failure.

It was also established that fifty-six percent (56\%) of the respondents did not own a business. This is an indication that 31 out of 55 respondents could not participate in AGPO initiative. The study concurs with the scholarly works of Gibbs that one approach of enhancing entrepreneurial activity and enterprise growth in Kenya is to create an entrepreneurial culture among the young through training and socialisation process (Nelson \& Mburugu, 1991; Gibb, 2000).

\section{Recommendations}

From the findings, the study recommends that the National Government and County Government of Isiolo together with other agencies such as Kenya School of Government and Development Partners should devise AGPO intervention strategies on ways of inculcating entrepreneurial culture among the youth through:

1. Capacity building Programs

2. Coaching and Mentorship Programs

3. Promoting Business Incubation Programs

4. Provide a conducive Legal and Regulatory Framework

5. Strengthen provision of seed capital among the youth to promote business Start Ups

These recommendations shall expedite the youth entrepreneurs in change of attitudes and mind sets, grow their business skills, and compete favourably in the Government business initiatives and attainment of Global, Regional and National Development Agendas.

\section{References}

Access to Government Procurement Opportunities (AGPO). (2015). Access to Government

Procurement Opportunities (AGPO). Retrieved on March 17, 2015, from Access to Government Procurement Opportunities (AGPO): www.agpo.go.ke

AGPO. (2017). Retrieved from Access to Government Procurement 
INTERNATIONAL JOURNAL OF ACADEMIC RESEARCH IN BUSINESS AND SOCIAL SCIENCES

Vol. 10, No. 4, April, 2020, E-ISSN: 2222-6990 @ 2020 HRMARS

Opportunities: http://agpo.go.ke/ www.ppoa.go.ke. (2017, 09 18). Retrieved from Public Procurement Code of Ethics for Procuring Entities - PPOA:

www.ppoa.go.ke/.../Public_Procurement_Code_of_Ethics_For_Procuring Entities.pdf

American Psychological Association. (2020). Publication manual of the American

Psychological Association (7th ed.). https://doi.org/10.1037/0000165-000

Callaghan, C. W. (2009) A Dissertation Submitted to the Faculty Of Commerce, Law and

Management, University of the Witwatersrand, Johannesburg, in Fulfilment of the Requirements for the Degree of Master of Commerce. Unpublished

David, D.., and Mark, F. (2012) Entrepreneurship and Small Firms Sixth Edition .McGrawHills Higher Education

Gibb, A. A. (2000b), 'Creating an entrepreneurial culture in support of SMEs', Small Enterprise Development, Vol 10, No 4, pp 27-38.

Government of Kenya (GoK). (2005). The Public Procurement and Disposal Act, No. 3 of 2005.Nairobi: Government Printer

Government of Kenya. (2015). The Public Procurement and Asset Disposal Act, 2015.Nairobi: Government Printer.

Government of Kenya. (2013). Public Procurement and Disposal (Preference and Reservations (Amendment No.2) Regulations, 2013. Nairobi: Government Printer.

Government of Kenya (2013). The Public Procurement and Disposal (County Government) Regulations. Nairobi. Government Printers.

Hivos East Africa. (2018). Impact of Kenya' Access to Government Procurement Opportunities (AGPO) law on youth women and persons with disabilities. http: www.eastafrica.hivos.org

International Labour Organization. (2009). Inclusion of People with Disabilities in Kenya.

Nairobi: International Labour Organization.

International Trade Centre, (2010). Understanding the Corporate Environment: MLS-SCM

Course Book Module 1, United Kingdom: International Trade Centre.

International Trade Centre (ITC). 2014. Empowering Women Through Public Procurement. Geneva, Switzerland:

Jackson, S. L. (2009). Research Methods and Statistics: A Critical Thinking Approach 3rd edition. Belmont, CA: Wadsworth.

Kenneth, R. A. (1989). Ethics in Practice: Harvard Business Review pp. 99-104, Volume 67

Kothari. (2009). Quantitative Techniques(3rd Revised Edition). Nairobi: Vikas Publishing House PVT Ltd. Kenyan Public Universities. Unpublished MBA project, Egerton University, Nakuru Kenya. Comesa Public.

Kenya National Bureau of Statistics. 2010 (KNBS). (2010). The 2009 Kenya Population and Housing Census. Nairobi: Population Reference Bureau.

Kenya Law. (2017, 09 18). Retrieved from Laws of Kenya: http://kenyalaw.org

Kuratko, D. F., \& Hodgetts, R. M. (2007) Entrepreneurship in the New Millennium. Cengage Learning India private limited.

Lagat, M. K., Namusonge, G., \&Berut, Z. (2016). Factors Affecting Youth, Women and Persons with Disabilities in Accessing Procurement Opportunities in Transnzoia County Government. 
INTERNATIONAL JOURNAL OF ACADEMIC RESEARCH IN BUSINESS AND SOCIAL SCIENCES

Vol. 10, No. 4, April, 2020, E-ISSN: 2222-6990 @ 2020 HRMARS

International Journal of Recent Research in Commerce Economics and Management (IJRRCEM). 3, (2)(42-66).

Lumpkin, R. D., \& Dess, G. G. (1996) Clarifying the Entrepreneurial Orientation Construct and Linking it to Firm Performance, Academy of Management Review.21,135-172.

Mahmood, R., \& Hanafi, N. (2013) Entrepreneurial Orientation and Business Performance of Women Owned Small and Medium Enterprises in Malaysia. Competitive Advantage as a Mediator. International Journal of Business and Social Sciences. Vol.4.No.1

Mahmood, M. (2010) 'British Must Move Fast to Profit on the Trade Front'. The Times 18th January 2005

Mapulanga, P. (2015). Public procurement legislation and the acquisition of library materials in academic libraries in Malawi. Library Review, 64(1), 101-117.

McCrudden, C. (2004). Using Public Procurement to Achieve Social Outcomes. Natural resources Forum 28 (pp. 257-267). Blackwell Publishing

Ministry of Youth A_airs. (2006). Kenya National Youth Policy. Nairobi: Ministry of Youth

A_airs. NGEC. (2017). Retrieved from National Gender and Equality Commission: http://www.ngeckenya.org/

Mugenda, A., and Mugenda, O. (2013). Research methods: Quantitative and qualitative approaches. Nairobi: ACTS PressMuraguri, J., (2013) Implementation of the youth preference and reservation policy in Public Procurement. The case of state-owned enterprises in Nairobi. The University of Nairobi. Unpublished.

Mwangi, P. N. (2017). Determinants of compliance with access to Government procurement opportunities regulations for special groups by public universities in Kenya

Nduta, C., Ayuma, C., Langat, B., \& Yego, S. (2015). Factors Affecting Youth Participation in Public Procurement in Kenya: A Survey of Youth Enterprises in Mombasa County. The International Journal of Business \& Management. 3(9)2321 -8916.

Ngugi, J., \& Mugo, H. (2011). Internal factors affecting procurement process of supplies in public sectors. Journal of Public Procurement, 1.

Nkonge, B. K. (2013). Challenges faced by Small and Medium Enterprise Suppliers when bidding for tenders. A case of Thika District. International Journal of Academic Research in Business and Social Sciences, 3(12)194

Obiri, L. (2016). Consultancy Onthe Assessment Of The Uptake Of 30\% Public Procurement Business Opportunities For Women, Youth and Persons With Disability At The County Level And Availability Of Business Development Services. Nairobi: Unwomen.

Odoyo, F., \& Lipindi, B. (2012) Compliance of Public Procuring Entities in Dar Es Salaam. Kampala International University.

PPOA, (2016). Kenya Power and Lighting Company Ltd Procurement Review Report. Retrieved from: http://www.ppoa.go.ke/images/downloads/review-reports/ Summary\%20of\%20review_Report-\%20kplc.Pdf

Public Procurement and Disposal Act. (2005). Kenya Gazette Supplement No. 77(Acts No. 3)

Public Procurement and Disposal General Manual. (2009). Public Procurement Oversight

Authority. Public Procurement and Disposal Regulations (2013).

Public Procurement Oversight Authority. (2007). Assessment of the Procurement System in 
INTERNATIONAL JOURNAL OF ACADEMIC RESEARCH IN BUSINESS AND SOCIAL SCIENCES

Vol. 10, No. 4, April, 2020, E-ISSN: 2222-6990 @ 2020 HRMARS

Kenya Public Procurement Oversight Authority. Retrieved from http://www.oecd.org/devt/effectiveness/41583965.pdf

Republic of Kenya. (2003) Kenya Vision 2030, A Globally Competitive and prosperous

Kenya.

Republic of Kenya. (2005) "Public Procurement and Disposal Act and Regulations"

Nairobi: Government Printers.

Republic of Kenya. (2013) Economic recovery for wealth and employment creation (2003-200

7) Nairobi: Government Printers

Republic of Kenya. (2013). Economic recovery for wealth and employment creation (2003-2007)

Nairobi: Government Printers

Quinot, G. (2013). Promotion of Social Policy Through Public Procurement in Africa. (pp.

370-403). New York: Cambridge University Press

Roodhooft, F., \& Abbeele, A. V. D. (2006). Public procurement of consulting services Evidence and comparison with private companies. International Journal of Public Sector Management, 19(5) 490-512.

Scott, R. (2004) 'China's legal framework for public procurement'. Journal of Public Procurement Vol.3 (3) 370-388

Simayi, S. (2005). Examination of Preferential Procurement, Enterprise Development and Corporate Social Investment with regards to the BEE draft codes of good practice Unpublished MBA Research Report, UCT Graduate School of Business.

Sutinen, J. G., \& Kuperan, K. (2009). A socio-economic theory of regulatory compliance. International Journal of Social Economics, 26(1/2/3) 174-193.

The Constitution of Kenya, 2010. (2010, August 27). Nairobi: The Government Printer, Nairobi Ugandan Experience. In G. Piga \& K. V. Thai (Eds.), Advancing Public procurement. Practices, Innovation and Knowledge-Sharing, 373-391

United Nations. (2017, 09 18). Retrieved from United Nations Global Market Place: https://www.ungm.org/Areas/Public/pph/index.html

UNCITRAL, (2014). UNCITRAL Model Law on Public Procurement. Vienna, Austria: United Nations.

Wanderi, C. (2014). Kenya: New Public Procurement Rules Good for Business. The African Executive.

Walker, H., \& Brammer, S. (2009). Sustainable Procurement in the UK Public Sector. Supply Chain Management: An International Journal, 14 (2): 128-37.

Wleh, N. P. (2013). Factors Influencing Youth Access To Public Procurement Opportunities In The Government Ministries In Kenya. UON. Unpublished.

Wittig, W. A. (2003). Public Procurement and the Development Agenda, International Trade Centre, Geneva. 